\title{
Developing future entrepreneurs: A need to improve science students entrepreneurial participation
}

\begin{abstract}
The current Malaysian system encourages school students to be involved in entrepreneurial activities. A study based on Theory of Planned Behaviour was conducted to investigate entrepreneurial intention and behaviour between "science" and "art" students in Malaysian secondary schools. Data were collected via questionnaire. A group of one thousand three hundred and fifty seven students participated in the study. Findings illustrate that "art" students following commerce and entrepreneurship subject scored higher means for all construct such as intention, subjective norm, social support and specific entrepreneurial efficacy. The study suggests that students with strong academic background especially in "science" program should be given proper entrepreneurship education and training to improve their active participation in the global economy as future entrepreneurial activities in order to create future entrepreneurial human capital.
\end{abstract}

Keyword: Developing Entrepreneur, Entrepreneurship Education, Science Education, Theory of Planned Behaviour Entrepreneurial Activities 